\title{
The incidence of structural racism in the employability by psychology students at a private higher education institution in Pernambuco - Brazil
}

\author{
Ana Paula Cândido Bezerra ${ }^{1}$; Anna Flávia Da Silva Cruz ${ }^{2}$; Beatriz Barros Cordeiro ${ }^{3}$; Fernando \\ Francisco da Silva Filho ${ }^{4}$; Juliane Pedrosa Jucá De Barros Brandt ${ }^{5}$; Priscilla Machado Montezano \\ Bastos $^{* 6}$; Pierre Teodosio Felix ${ }^{7}$
}

$1-6$ Psychology students at the University Center of Vitória de Santo Antão -UNIVISA

7 Professor of the Psychology Course at the University Center of Vitória de Santo Antão -UNIVISA

E-mail adresses: pmontezano73@gmail.com (Priscilla Machado Montezano Bastos)

${ }^{*}$ Corresponding author

\section{To cite this article:}

Bezerra, A.P.C.; Cruz, A.F.S.; Cordeiro, B.B.; Filho, F.F.S.; Brandt, J.P.J.B.; Bastos, P.M.M.; Felix, P.T. The incidence of structural racism in the employability by psychology students at a private higher education institution in Pernambuco - Brazil. International Journal of Sciences. Vol. 2, No. 1, 2021, pp. 26-30. ISSN 2763-5392.

Received: 06 29, 2021; Accepted: 06 30, 2021; Published: 07 15, 2021

\begin{abstract}
Slavery emerged in antiquity reflecting to this day, like racism. In schools and corporate environments, this discriminatory act reveals that Brazilian racial democracy needs to be conquered. This reflection is observed in relation to employability because companies still decide hiring considering the ethnicity of the candidate. Thus, it is important in Brazil to create programs of qualification and professional ascension for blacks, being a path of social evolution in racial equity. With the pandemic caused by Coronavirus, some social problems experienced by the black population such as an increase in the percentage of unemployed and the decrease in the occupancy rate were reported by Daniel Silveira and Marta Cavallini in G1. Based on literature analyses and discussions based on the results of the questionnaire, this article shows the historical burden up to our present moment in relation to ethnicity and employability among students of the 9 th/10th psychology periods at a private higher education institution in Pernambuco - Brazil.
\end{abstract}

Keywords: Employability; Unemployment; Racism

\section{Introduction}

The black man's slavery began before the slave trade. It began among the African communities themselves that were enslaved whenever they lost some territorial dispute. But a historic event made slavery something local to gain the world, it was the occupation of Egypt and North Africa by the Arabs between the end of the 12th and the mid-13th century. Centuries later, already in Brazil, slaves were considered properties, being auctioned and sold as merchandise. They worked in the most diverse economic sectors of the time, such as coffee plantations, gold extraction, agriculture, cattle raising, among others. And so, slave labor was responsible for most of the wealth produced in the country for over 300 years. "Slavery was much more than an economic system. It shaped conduct, defined social and racial inequalities, forged feelings, values, and labels of command and obedience." It was a society that made it very clear the place of each individual, who commanded and who obeyed. This class society characterized colonial and imperial Brazil as a slaver (ALBUQUERQUE and FILHO, 2006).

The living conditions of the slaves were deplorable. Their clothes were precarious, distributed twice a year, food was scarce and without quality, they were subjected to countless physical abuses that could even lead to death and forced to work up to 18 hours a day. This condition was the cause of the low life expectancy of this population (PÔRTO, 2006).

At the end of the 18th century, with the emergence of various abolitionist movements, the slave system was condemned and banned in much of Europe and the American continent. This wave eventually arrived in Brazil, but it was only in the mid-nineteenth century, with the prohibition of trafficking, that this agenda was in fact considered and debated. With the end of trafficking "they believed that with the high mortality rates of the slave population, and without 
the possibility of renewing them through trafficking, slavery would fall a part in a few decades. On the other hand, the slaves, increasingly aware of the moment they lived in, accelerated this process with escapes, formation of quilombos, rebellions, etc. (MOURA, 1983).

In 1860, Brazil and Cuba were the only countries that had a slave system. This left Brazil in an uncomfortable situation compared to the rest of the world where there was no more slavery. Trying to balance international pressure with the demands of slave owners, D. Pedro II approved measures that subtly made the country even closer to abolition, such as the prohibition of slaves in the construction of public works and the prohibition of punishments with whips, slaves under 15 could no longer be separated from their mothers, among others (BERBEL, MARQUESE and PARRON, 2010).

The most important law prior to abolition was the Free Wombat, passed in 1871. This law, in addition to making free all newborn sand slaves, "created emancipation funds, which freed captives with money from taxes on slave property, lotteries, fines for those who disrespected the law and appropriations from public budgets." Another important factor for slave liberation in Brazil was the abolitionist movement that began in 1860 and was gaining strength over the years, having as supporters' people of all classes and social levels, including intellectuals of the time. Although some advances have been made toward freedom, these advances had few effects and gave the impression that their realization would not happen anytime soon. This awareness led the abolitionist movements to intensify their actions, "encouraging escapes or giving hiding to escaped slaves, preventing the sale to other provinces and creating countless situations to derail captive work in the cities." (ALBUQUERQUE and FILHO, 2006).

Between 1870 and 1880, abolitionists had great success in their actions throughout the country, increasingly weakening the power of slave owners. All these movements culminated in the definitive extinction of slavery, through the Law of May 13, 1888, the Law of The Aurea, signed by the princess regent, Isabel. The law that ended a system of more than three centuries had only two clauses and none indemnified the slave masters or brought any compensation to the newly freed. It was still met with celebration throughout the country. Black people celebrated their right to come and go, religious freedom and their new citizen status. With no guarantee of land or education by the government, much of the blacks remained in their workplaces with demands that few homeowners were willing to negotiate. This is how the black Brazilian found himself renegade to underemployment, poverty and the periphery. Situation that lasts to our day. (GEBARA, 1986).

\section{Employability of blacks in today's world}

With the end of slave labor and the Proclamation of the Republic, the monopoly of power, control over the state and political dominance are now exercised by the great owners. (MARTINS, 2012)

We know how much unemployment affects people in today's world, but this event does not apply to everyone equally, it mainly affects the black population. Even after 130 years of the abolition of slavery we can still see this inequality continuously in our society. According to a survey by students of Social Sciences at PUCRS, blacks earn $17 \%$ less than white individuals coming from the same social condition, and another conducted in 2019 by IBGE points out that whites earn $68 \%$ more, from these surveys we can already see how much wage inequality is extremely high (LOPES, 2020).

Some authors comment on how much structural racism has influenced since hiring black people, as well as explaining how racist companies are still and are far from achieving racial equality.

"Structural racism is not only present when people commit offense. The behavioral face is just the tip of the iceberg. As a structure of oppression, it operates in the unconscious, reflecting on the most diverse issues, such as aesthetic apprehension and under-representation", defends Bersani (apud ALMEIDA, 2017).

Working conditions for blacks were no longer the best and with the pandemic caused by Sars-CoV-2 or Coronavirus, they are the most affected by the crisis, among the problems caused is the unemployment rate that increased significantly for this population. Even though some blacks live in a similar situation or similar to whites, some tend to have a lower education level, therefore an influence on low income in the labor market. Everyone needs to have an open vision for racial inequality, it is a historical situation experienced to this day, passing through schools and influencing the employability situation of these people. (SILVEIRA, CAVALLINI, 2020).

This lack of placement of blacks in the labor market makes the country less and less democratic and developed, thus showing that the racial democracy that people think exists is far from consolidated. As much as black people have more space today than they have been years ago, they still do not hold positions with great social prestige, or in places acclaimed as in politics. They still remain in manual positions, where qualification and schooling are not aspects of great value (HERINGER, 2020).

"More than a century after the abolition of slavery, manual labor remains the place reserved for Afro-Brazilians. As opposed to what theories about modernization have stated, the transition structure provided by rapid economic growth in recent decades does not seem to have contributed to significantly reducing the gap between racial groups present in the population" (Hasenbalg, 1996:15 apud Heringer, 2002).

As the report on racial inequalities in the labor market states, "the State must invest in public policies and actually implement ILO Convention 111, inversing the logic of the opportunity structure, which is deeply marked by practices that violate rights and discrimination based on race and sex" (INSPIR/DIEESE/AFL-CIO, 1999:8 to HERPUDINGER 2002).

Considering that Brazil was the last country in America to abolish slavery, the reflections of this period, such as racism, persist in contemporary society. A study in this field is relevant because even though there is "freedom" in the post-abolition, the logic of slavery persists in the conditions of dignified living denied to blacks (social relations have not 
changed). Another factor that contributed to the established and still existing racial prejudice was the contribution of science, which for some time attest to the superiority of whites and justified the inferiority of blacks by the "early ossification of cranes" (RODRIGUES,1935). The denial of the existence of racism is another obstacle to its real disappearance. This issue is important for harmonic social growth on Brazilian soil. Bringing vulnerabilities and social differences to the space of research and science enriches the construction of a true Brazilian racial democracy for future generations.

This research aims to discuss racism and employability among students graduating from the second semester of 2020 and the first semester of 2021 of the psychology course of the University Center of Vitória de Santo Antão in the state of Pernambuco. This study aims to investigate whether the employability indexes of this group are influenced by the ethnicity of the interviewees. The data collection technique used was a semi-structured questionnaire research instrument, from which the results of the present analysis derive.

\section{Methodology}

In this work, the technique of data collection of the research was through google-type questionsthat servedas the basis for statistical analysis in the Software SPSS v. 22.0. and sent tothe students of the 9th/10th periods of Psychology at a private higher education institution in Pernambuco - Brazil through a link.

\section{Results and Discussions}

From the questionnaires applied, 25 respondents were obtained and thus it was found that $64 \%$ of the interviewees were between 18 and 30 years old (Table 1), 92\% were female (Table 2) a fact addressed in the literature by BRUSCHINI, 1979 and $64 \%$ of all interviewees were single. Regarding education, $80 \%$ of the students are in higher education, although in progress.

Table 1: Percentage of age

\begin{tabular}{|ll|r|r|r|r|}
\hline \multicolumn{6}{|c|}{ IDADE } \\
\hline & & Frequência & Porcentagem & $\begin{array}{c}\text { Porcentagem } \\
\text { válida }\end{array}$ & $\begin{array}{c}\text { Porcentagem } \\
\text { acumulativa }\end{array}$ \\
\hline Válido & 18 1830 & 16 & 64,0 & 64,0 & 64,0 \\
& 31e40 & 6 & 24,0 & 24,0 & 88,0 \\
& 41e50 & 2 & 8,0 & 8,0 & 96,0 \\
& 51acima & 1 & 4,0 & 4,0 & 100,0 \\
& Total & 25 & 100,0 & 100,0 & \\
\hline
\end{tabular}

Table 2: Gender of the interviewees

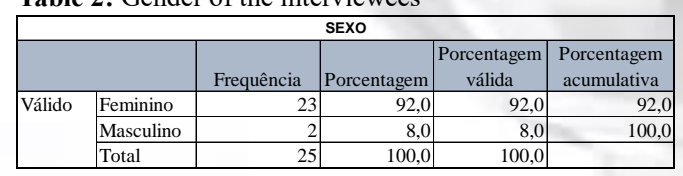

An important result of this study was the analysis of the ethnicity of the interviewees where only $40 \%$ declared themselves as brown or black. This indicates according to the 2011 Census of Higher Education, that the representativeness of blacks in higher education is lower. (Figure 1) In the analysis of the income range, $64 \%$ have salaries of up to three minimum wages and $36 \%$ income above three minimum wages. In the analysis about age in the first job, $92 \%$ started their professional life between 18 and 30 years. Only two respondents started their professional life at a minor age and both declared themselves brown. (Figure 2).

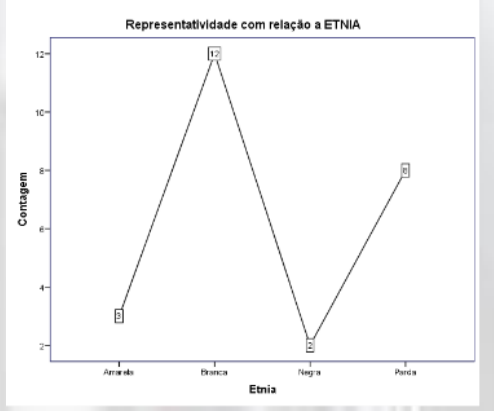

Figure 1. Simple line chart that demonstrates relationship between the ethnicities of the interviewees. Generated by SPSS v. 22.0

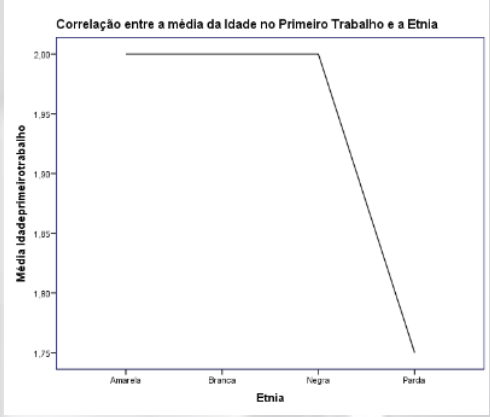

Figure 2. Simple line chart that demonstrates relationship between age and first job. Generated by SPSS v. 22.0.

In the answers, $40 \%$ of whites and yellows and $50 \%$ of blacks and browns are unemployed. (Figure 3 and 4 )

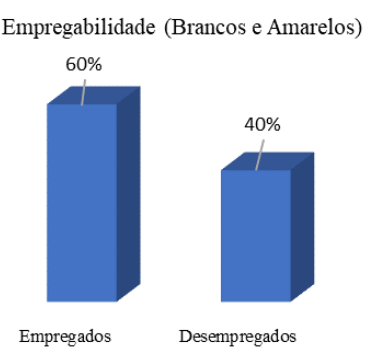

Figure 3. 3D graph demonstrating employability between whites and yellows. Generated by SPSS v. 22.0.

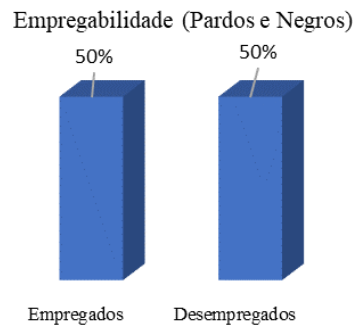

Figure 4. 3D graph demonstrating employability between blacks and browns. Generated by SPSS v. 22.0. 
Only $12 \%$ have felt discriminated against by their skin color or witnessed racist attitudes in the workplace, which demonstrates an evolution in racial democracy. In one of the questions of the research instrument, we asked about the presence of blacks in leadership positions and $84 \%$ (Figure 5) of the interviewees agree that the higher the position, the lower the representativeness of black people, a fact observed by COUTINHO, 2008. A large percentage $(96 \%)$ agrees that training and ascension programs for black leaders are important to our social context. (Figure 6).

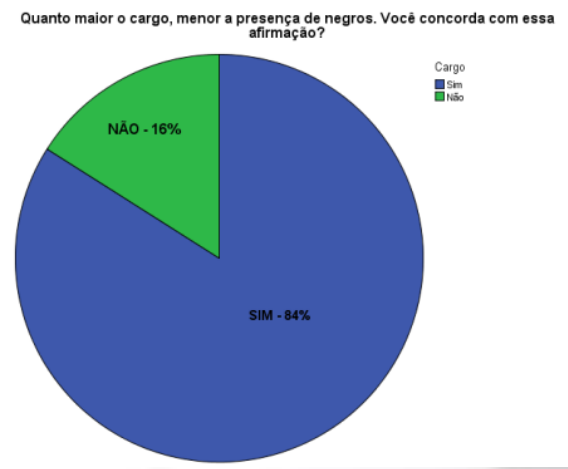

Figure 5. Graph that represents the opinion of the interviewees regarding the occupation of blacks in high positions. Generated by SPSS v. 22.0.

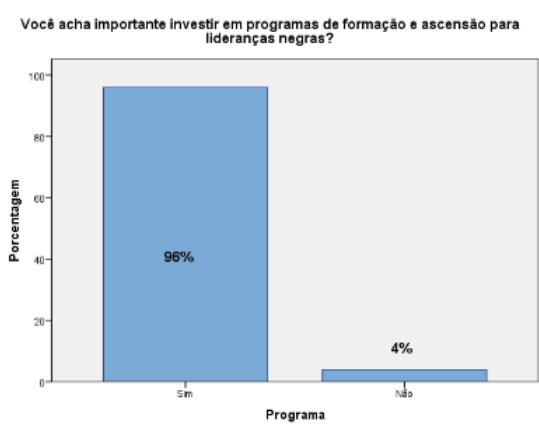

Figure 6. Graph that represents the opinion of respondents regarding investment in corporate programs for black leadership. Generated by SPSS v. 22.0

Only $24 \%$ used a public vocational training program. The last question asked whether some jobs or professions are determined by skin color and more than half of respondents $(52 \%)$ agrees that yes (Figure 7$)$.

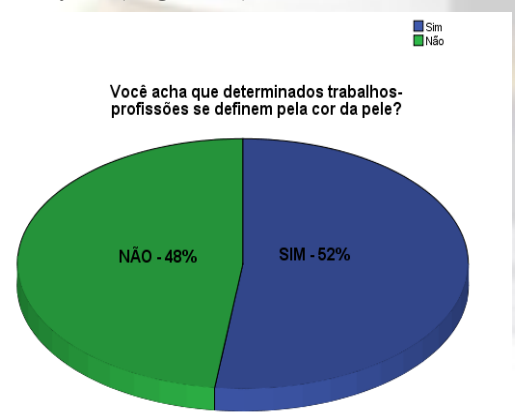

Figure 7. Graph that represents the opinion of the interviewees regarding skin color and type of employment. Generated by SPSS v. 22.0 .
In the sample of this study we observed some points that make the correlation between employability and racism possible. Like the unemployment rate for black and brown ethnicity is higher than for whites and yellows. In the sample of this study most of the people who responded are women. Observing the questionnaire, we noticed that most of them started their professional life between 18 and 30 years old, only two people entered the labor market as children, and the two declared themselves brown. Regarding the occupations of leadership positions in companies, the majority agree that the higher the position, the lower the representation of blacks, thus racism was evidenced, while $12 \%$ of people have felt discriminated against by skin color or have witnessed some act of racism.

\section{Conclusions}

In view of the above, it was concluded that the history of slavery in Brazil reflects in contemporary society with episodes of discriminatory acts, in expressive racial democracy and in the rates of employability among blacks as well perceived in the analyses of this work. Perhaps if content on racial democracy and racism is included in the curricular components of students and in the practice of family dialogue more opportunities will arise for children and young people to understand and interact with reality contributing to the social evolution of Brazil. We believe that society is more aware of the need to institute public and private actions that promote racial equity, because in this survey $96 \%$ think it is important to invest in training programs for black leaders. The literary review demonstrated the wage difference between whites and blacks, besides pointing out that the employability index is lower between blacks and browns, a fact that was proven in the results of our research. In the contingent of graduates of the psychology course at a private higher education institution, we observed that there is the analysis of the correlation between ethnicity and employability, while $50 \%$ of blacks and browns are unemployed, only $40 \%$ of whites and yellows share the same situation. The percentage of students who declare themselves black and brown was $40 \%$, confirming the lower representativeness of these races in this class in Higher Education. Another factor that reveals the presence of structural racism in our culture is that the majority of respondents agree that there are professions that are defined by skin color, demonstrating to have a view on the presence of racism and its effect on employability. From the results, we used a new study, with respect to $92 \%$ of the students being female in the psychology course indicating an opportunity of research to understand what influences this percentage, among social and cultural patterns, psychological mechanisms, etc.

\section{References}

[1] ALBUQUERQUE, Wlamyra R. de; SON, Walter Fraga. A story of the black in Brazil. Salvador: Center for Afro-Oriental Studies, 2006.

[2] ALMEIDA, Lucas. Structural racism influences labor relations. AUN - UNIVERSITY NEWS AGENCY USP, São Paulo, 12/20/2017. Available in: 
https://paineira.usp.br/aun/index.php/2017/12/20/racismoestrutural-influencia-relacoes-de-trabalho/ $>$

[3] BRUSCHINI, Maria Cristina Aranha. "Sexualization of occupations; the Brazilian case." Cadernos de Pesquisa, São Paulo (28):5-20, Mar., 1979.

[4] COUTINHO, I.A. CARVALHO, L. R. S; J. L. F. Debating Gender and Race Diversity in the Brazilian Organizational Context: Market Law or Quotas by Law? 2009, available at: $<\mathrm{http} / / / w w w . a e d b . b r / s e g e t / a r t i g o s 09 / 417$ 417_Debatendo_div ersidade_de_Geero_e_Raca_no_Contexto_Organizaional_Bra sileiro.pdf $>$, accessed: $11 / 0 \overline{5} / 2014$.

[5] GEBARA, Ademir. The Free Labor Market in Brazil (18711888). Ed, ed. Brasiliense, São Paulo, 1986, p. 205 e207.

[6] HERINGER, Rosana. Racial inequalities in Brazil: synthesis of indicators and challenges in the field of public policies. cad. Public Health, Rio de Janeiro, n. 18, p. 57-65, 2002.

[7] LOPES, Janaína. Blacks earn 17\% less than whites of the same social origin, according to a study by PUCRS. G1 RS, Rio Grande do Sul, 20/11/2020. Available in: < https://g1.globo.com/rs/rio-grande-dosul/noticia/2020/11/20/negros-ganham-17percent-menos-doque-brancos-da-mesma-origem-social-aponta-estudo-dapucrs.ghtml >

[8] MARTINS, Tereza Cristina Santos. The negro in the context of the new strategies of capital: unemployment, precarious and informality. Serv. Soc. Soc., São Paulo, n. 111, p. 450-467, Sept. 2012.

[9] MOURA, Clovis. Brazil: the roots of black protest. São Paulo: Global, 1983.

[10] NASCIMENTO, André José de; MEDEIROS, Maria da Glória de. The end of slavery and its consequences. In: Electronic Annais of the IV Colloquium of History "Interdisciplinary Approaches on the History of Sexuality". Luiz C. L. Marques and Newton D. A. Cabral (Orgs.). Recife, October 16-19, 2010. p. 309-316. ISSN: 2176-9060. Available: http://www.unicap.br/coloquiodehistoria/?page_id=42.

[11] PEREIRA, Noronha Isadora. 'BROOKLYN NINE-NINE': CHECK OUT 5 SOCIAL ISSUES ADDRESSED IN THE SERIES. This is Universities, 13/05/2020. Available in: < https://falauniversidades.com.br/brooklyn-nine-nine-confira5-questoes-sociais-abordadas-na-serie/ >

[12] PORT, Angela. The slave health system in 19th century Brazil: diseases, institutions and therapeutic practices. História, Ciências, Saúde-Manguinhos, Rio de Janeiro, vol 13, $\mathrm{n}^{\circ}$ 04, Oct/Dez, 2006.

[13] SILVEIRA, Daniel; CAVALLINI, Marta. Pandemic increases racial inequality in the Brazilian labor market, official data show. G1, Rio de Janeiro and São Paulo, 11/17/2020. Available in:

https://g1.globo.com/economia/noticia/2020/11/17/pandemiaaumenta-desigualdade-racial-no-mercado-de-trabalhobrasileiro-apontam-dados-oficiais.ghtml $>$

[14] SILVEIRA, Daniel. 'Structural racism' is the biggest obstacle for the black population in the labor market, activists say. G1, Rio de Janeiro, 11/20/2020. Available in: $<$ https://g1.globo.com/economy/news/2020/ 11/20/racismstructural-and-major-barrier-to-population-negra-nomandrcado-de-trabalho-say-activists. ghtml > 